\title{
1 \\ Only Ten: Islands as Uncomfortable Fragmented Polities
}

\author{
Godfrey Baldacchino
}

\section{The setting}

The existence of multiple jurisdictions on distinct continental spaces raises no eyebrows. There are 54 countries in Africa, 50 countries in Europe, 44 in Asia, 23 in North and Central America and 12 in South America. Nor do we habitually consider Africa, North America or South America (let alone Eurasia) as islands, even though - since the carving of the Suez and Panama canals - they would each qualify as pieces of land surrounded by water. Perhaps that is because a continent is often deemed too large to be considered an island. But there is another truism to be considered: that an island deserves a unitary polity. Islands are such special places that they should only be run by, and as, a single administration. How else could one explain Australia, not exactly a small territory, being called an island continent? If Australia is successfully conceptualised as an island - apart from being a continent - this may result not so much by virtue of its size - which is considerable, since it is almost as large as Europe - but by virtue of the fact that it has been, since January 1901, a single country (McMahon 2010).

It is true that there are various practical and logical conveniences in having an island administered as a single political unit. Discrete pieces of land separated by stretches of water from mainlands are difficult to administer from afar, by 'remote control', without a modicum of local administration. There is therefore a logistical tendency and preference for an island to be self-administered, especially if distant from its metropolitan power (Peckham 2003: 503). But, there also seems to be some difficulty - conceptual, political, emotional, imaginary and symbolic - with accommodating more than one sovereign state on the same island space. 


\section{PROOF}

2 Only Ten: Islands as Uncomfortable Fragmented Polities

Even the hugely popular cartoon fictional character Popeye the Sailor Man finds himself embroiled on a divided island. In 'Chapter III: The Great Rough-House War', Popeye is unwittingly recruited on behalf of King Blozo and the Nazilian Army to lead the fight against 'the cowardly Tonsylanians' led by King Gargileo (Segar 1931/2007: 32). The 'great war' is unfolding on the Addynoid Islands, and the map shows a bare, oval-shaped Pacific island neatly divided by a straight line between the two warring kingdoms (ibid.). The subject matter is clearly humorous - all the names are contrived from the human nose and mouth region - but there is apparently, even in the world of cartoon strips, no better or more poignant way to dramatise a division than by having two warring factions living cheek by jowl on the same, small piece of land in the middle of a vast ocean. The dispute is suggested to be a petty affair, and its unfolding on the same small and remote island adds to its overall insignificance. Jonathan Swift might have done even better to emulate this example and locate Lemuel Gulliver's adventures in Lilliput and Blefuscu on the same island, rather than have two distinct warring island kingdoms, separated by an 800-yard channel (Swift 1726: part I).

There are many islands and archipelagos in the material world, and in some cases they are subject to the competing claims of various regional powers. Consider Mayotte in the Indian Ocean (contested between France and the Comoros); Hans Island/Tartupaluk in the Nares Strait (claimed by both Canada and Greenland/Denmark); Iturup and Kunashir Islands, in the Kurile Group (occupied by Russia but claimed by Japan); and Dokdo/Takeshima (claimed by both Japan and South Korea); and the 250-or-so islands in the South China Sea, including the Spratly Islands, for which claims have been submitted by no less than six countries. However, what is striking here is that, in all these and other cases, the submitted claims for sovereignty are usually to whole islands, not to parts thereof. "In fact, only very rarely are islands divided between nation states" (Royle 2001: 150). There are today only ten inhabited islands whose territory is divided amongst two or more countries. (Or 11, if one adds Sebatik Island, alongside Borneo.)

\section{Islands as absolute spaces}

But an island is a naturally closed entity. Its shoreline is the boundary of the bubble separating it from the rest of the world. And then impose a human-made barrier on an island? What is the meaning of 


\section{PROOF}

Godfrey Baldacchino 3

isolation - a word derived, in fact, from the Latin for 'island' - if you have to share it with someone else?

(Jacobs 2012)

Islands, like the maps that frame them, present themselves as absolute spaces. They are easily imaginable wholes; they are not arbitrary (Jepson 2006: 158). Being geographically defined, and often imagined as circular, an island is easier to hold, to own, to manage or to manipulate, to embrace and to caress. Is this part of the reason why so many islands are self-contained jurisdictions? Just as much as anyone finding oneself on, or close to, an island finds early on a craving to circumnavigate, circumambulate or climb its highest point and 'take it all in' (e.g. Baum 1993: 21 , Redfield 2000). A drawn island thus tends to fit quite nicely onto a sheet of paper. Is it their boundedness and separation that make islands so attractive to fantasy and mythology? Their beguilingly simple form often perceived to approximate a circle, that perfect shape - makes the exercise easier, as well as somehow more perfect (Baldacchino 2005a). Utopia, Thomas More's perfect commonwealth, had to be located on a befittingly 'just right' island space: it was enisled, cut away from its original peninsula (More 1516).

The reference to Utopia, and its deliberate islanding, reminds us that islands are also sites for thinking about how to govern; about changing understandings of territory, security and sovereignty (Baldacchino 2010). Islands represent quintessential platforms for nation states: they are delineated spaces and discrete bounded territories that are at once knowable and, because of their consolidated, readily defensible form, also function as ideal embodiments of the state's relationship to the nation (Peckham 2003: 503). Such a finite and self-evident island geography smoothens the nurturing of a sense of identity that is contiguous with territory (Anckar 2005, Baldacchino 2005b, Srebrnik 2004). Perhaps this condition is one strong explanation for the existence of such few islands in the world today that are divided between more than one country. The political map of the world ushered in after the Treaties of Westphalia (1648) abhors divided islands: countries, and nations, on continents may be carved up by politicians in various ways, and often driven by expediency or compromise; but countries on islands are fashioned by God and/or Nature, and are not - or should not - as easily to be tampered with. To reach such a conclusion is to fall into the 'territorial trap': uncritically accepting the notion of territory as embedded in modernist ideas about the state as a fixed unit of sovereign, material space (Agnew 1994). 


\section{Only Ten: Islands as Uncomfortable Fragmented Polities}

The elimination of divided islands in recent centuries has indeed proceeded hand in hand with the march of the richly imagined nation state as the default jurisdiction of choice. Prior to the age of the nation state, islands have often been divided: islands such as Sicily (now part of Italy) and Euboea (now part of Greece) were long divided amongst several city states; Tasmania (now part of Australia) was divided between various indigenous tribes prior to European colonisation; mainland Australia itself was effectively run as a series of separate colonies before 1901 . Islands such as Corsica (now part of France), Efate (Vanuatu), Elba (Italy), Long Island (New York, USA), Newfoundland (Canada), Sakhalin (Russia), Sardinia (Italy), St Kitts (St Kitts-Nevis), Ternate (Indonesia) and Tobago (Trinidad and Tobago) may now each be territories of single countries, but they have all spent periods of their history as divided places. Until as late as 2008, Sri Lanka was a de facto divided jurisdiction, with the separatist Tamil Eelam coexisting with the official state. Mindanao, in the Philippines, remains in a similar predicament, with a well-entrenched separatist Muslim movement - the Moro Islamic Liberation Front - in control of a significant part of the island. Perhaps the best-known example of a long-divided island that became a single sovereign state in 1707 via 'Acts of Union' is Britain: a union, however, whose days may be numbered if Scotland votes 'yes' in an independence referendum due in 2014 .

That the status of divided islands is problematic or uncomfortable is also evidenced by the tensions that have historically existed between many of those states that find themselves sharing the same island space. Most of the divided islands showcased in this collection spent some time as a single political entity, even if (as in the case of Borneo and Timor) for a few years as Japanese-occupied territories during the Second World War. In other cases - Bolshoi Ussuriiskii/Heixiazi, Cyprus, Hispaniola/Quesqueya, Ireland, Tierra del Fuego, Usedom/Uznam and again Timor - one or more of the concerned powers, or constituent organisations thereof, would have coveted (or even controlled, for some time) the whole island, and would typically have tried to either prevent or undo its division, arguing that unification offered a 'better' and a more 'natural' status. And, in most cases, nationalism and politics apart, there are today serious attempts at crafting transnational economic zones of cooperation from which both sides seek to benefit, even if just to reduce dangerously high border tensions. Indeed, divided islands often have a sui generis trans-border political economy, which is what much of this book is about. 


\section{PROOF}

Godfrey Baldacchino 5

\section{Islands and idiosyncratic governance practices}

Recent history continues to throw up examples of political exceptionalism, and islands are very well represented.

The uninhabited island continent of Antarctica is one such place: geography and serendipity have delivered it to the modern world in a shape that has somehow reconciled the traditional states-based rivalry over rights and duties on an entire continent, where a few claimed territorial prerogatives, others denied these in principle or detail, and most of the globe was denied standing at all. Its 20th-century model of governance - the Antarctic Treaty System - remains idiosyncratic; what is more worrying is that it is becoming fragile as states become even more aggressive in extending their territorial rights in search of lucrative mineral deposits (Hemmings et al. 2012).

From the 17th through the late 19th centuries, Svalbard (also known as Spitzbergen), in the Arctic Circle, hosted only seasonal habitation by European and Russian whalers. In 1906, the Americanowned Arctic Coal Company founded the first permanent settlement, the town of Longyearbyen, which was soon sold to Norway's Store Norske coal company. This permanent Norwegian presence was, perhaps, a fateful circumstance: the Spitsbergen Treaty, signed following the First World War, granted Norway sovereignty over the islands; nevertheless, the treaty's other signatory states could undertake economic (mainly mining) activities on the islands, and the territory was partially demilitarised. Thus, for most of the 20th century, human settlement in the Svalbard archipelago primarily took the form of coal mining company towns operated by Norway and USSR/Russia. Today, Longyearbyen is a multinational town, featuring a fledgling local democracy that at times clashes with the archipelago-wide jurisdiction exercised by the Norwegian-appointed governor (Grydehøj et al. 2012).

Until 1975 part of the four-island French Overseas Territory of the Comoros, Mayotte voted to remain French, thanks largely to manoeuvres by the Paris government, while the other three islands declared independence unilaterally, but on behalf of all four (Newitt 1984). The UN accepted the new state as consisting of all four islands. Since then the dispute has dragged on. The Comoros has meanwhile been battling internal secessionist tendencies and opted for a federal structure to try and assuage these. In 2011, Mayotte became a French overseas regiondepartment (and the only one with a significantly Muslim population); 


\section{Only Ten: Islands as Uncomfortable Fragmented Polities}

it will probably become an EU Overseas Region in 2014. France justifies and seeks to build legitimacy for its continued 'occupation' of Mayotte by writing a historical narrative which detaches Mayotte from the other islands (Muller 2012).

Tuvalu (formerly Ellice Islands) had the unique experience of separating from the Gilbert and Ellice Islands by agreement before independence. As the British colonial administrators introduced representative institutions from the 1970s, tensions developed between Micronesian Gilbertese, resenting disproportionate Ellice success in the civil service, and the Polynesian Ellice Islanders sensing their permanent minority status in the legislature. After a thorough report in 1973 and a referendum in 1974, British officials still doubted whether a separate country of 9,000 would be viable, but they feared unilateral secession. Separation followed in October 1975 and the former eight inhabited islands of the Ellice Group achieved independence as the state of Tuvalu - which means 'eight standing together' - in October 1978 (McIntyre 2012). The lingering secessionist tendencies of even small archipelago states and territories - think of Anguilla, Aruba, Nevis and the Netherlands Antilles - are often referred to as 'the Tuvalu effect'.

But perhaps the best-known and most notorious case of all concerns Guantánamo: the United States continues to detain suspected terrorists and enemy combatants in 'legal limbo' on its sprawling $115 \mathrm{~km}^{2}$ island base at Guantánamo Bay, an enclave on the island of Cuba, granted in perpetual lease to the US under the 1903 Cuban-American Treaty (Supreme Court of the United States 2004). In choosing a place that is physically outside the nation itself, the US administration has kept various arrested persons 'abroad in a cynical attempt to delocalise liability on the use of torture' (Bigo 2007: 19). Guantánamo Bay has effectively been crafted as a 'juridical limbo', a 'zone of indetermination', a 'carefully constructed legal absence' and a field of experimentation because it is a threshold where the border between inside and outside is uncertain (Bigo 2007: 17-18, Butler 2002, Fletcher 2004, Reid-Henry 2007: 630). Guantánamo has become 'an ambiguous space both inside and outside different legal systems' (Kaplan 2005: 833). This situation recalls that of refugees (mainly from Haiti, but also from Cuba itself) held at Guantánamo Bay in the 1980s and early 1990s: they were denied any rights to appeal for asylum on the grounds that they were in a 'lawless enclave' outside US jurisdiction (Kaplan 2005: 839, McBride 1999). In spite of promises by the US Obama administration to close it down, Guantánamo Bay persists as a 'legal black hole' (Lopez 2010). 


\section{PROOF}

Godfrey Baldacchino 7

\section{This collection}

This edited collection is the first ever focused study of the intriguing and unique political economy of these rare, shared island spaces. It examines the fascination, and obsession, with islands as unitary geographies and polities, and explores the tensions in contemporary 'divided islands' as in the case of formal and informal, legal and illegal 'border crossings' and practices - from both an 'island studies' and an 'international relations' perspective. It also offers comparative insights that can be considered by scholars of other divided but non-island territories, such as Palestine, Korea and Somalia.

This collective work provides an interesting twist to the post-colonial experience. Admittedly, '[i]sland stories have tended to slip the net of postcolonial theorising' (Edmond and Smith 2003: 5). But, even within islands, the stories of these ten are even more exceptional. Some of the largest of these - New Guinea, Borneo and Hispaniola, but also Timor were long fragmented into separate kingdoms or tribal chiefdoms before the onset of Western colonialism. In their case, it was the lingering presence of more than one colonial power that eventually led to a reduction of polities to the current two-way division (and the three-way split for Borneo). But, in most cases ' $[w]$ hat becomes clear... is that each of [the world's divided islands] became divided after interference from the outside, be this colonialism, migration, or invasion - sometimes all three' (Royle 2001: 152). The territories involved - with the exception of French St Martin/Dutch Sint Maarten, each of which remains totally disinterested in independence - have had not just to contend with a transition to full sovereignty as, or as parts of, decolonising states, but to warily watch over their shoulders at their neighbour's own transformation and its territorial and nation-building designs. There are many cases of violence (and even more threats thereof) that have preceded, accompanied and followed the islands' divisions. But there are also many examples of 'trade' - from fruit and vegetables to manufactures; from smuggling of immigrants to tourism - that may operate through official border posts and protocols, and that may not. And there is the role and influence of 'third parties': supranational bodies like the European Union, regional powers like the US and Australia, neighbouring states and multinational corporations who may have an eye on lucrative mineral deposits - copper, gas, gold, oil - on land or in the sea and smaller 'stateless nations', with independence-leaning political parties waiting and watching closely to see how to advance their own claims to sovereignty (Baldacchino and Hepburn 2013). 


\section{Border matters}

Borders reflect humanity's need for obstacles, for a line in the sand between Them and Us -

Jacobs (2011)

An island's boundary - where it meets the sea - is self-evident and non-negotiable. In contrast, a land boundary, almost by definition, is contestable: it can be changed, shifted to suit, reflecting power politics, the outcome of victor and vanquished in warfare or negotiated compromise. And then there are the ten inhabited islands where both these dynamics pan out.

This collection is also a study of the flexibility of borders. While always being at the edge, borders are powerful symbols of the reach of the state and its territorial powers. Theirs is a symbolism that inculcates a sense of identity as much as of alterity; of security as much as of threat. Borders keep people in as much as they keep people out. Whether one is dealing with the deliberately invisible border on St Martin/Sint Maarten, the completely fenced and UN-patrolled Green Line on Cyprus or the exclave of Oecussi in Timor, the world's divided islands must contend with a specific political economy, a space of transition which can only partly be regulated, but whose reality and representation of the Other is an important and unavoidable constituent of the national psyche. There are clear, often explicit relationships between a state's material indivisibility and discourses of national identity, to the extent that the portrayal of the national territory is often done at the expense of the island's comprehensive geography. Of course, this is habitually done by all states, but does it not look especially contrived when the rest of an island space simply goes missing from the political map? One wonders how the tensions between any unitary island imagination and the stark symbols of its violation - by such statist artefacts as flags, borders, checkpoints and currencies - are habitually represented, projected and constructed beyond cartography: as in literature, art, song and music.

But then, and to the chagrin of their guardians, borders always leak. In spite of the necessity of bordering, there are always considerable temptations and incentives to cross the border. Where erstwhile national divisions may have resulted from colonialism and state building, locals may navigate across borders almost with the same impunity and inconsequentiality of their forebears: properties, fields, hunting grounds, their very relatives may be found in what are today different countries. Spoken languages trickle over state frontiers. There are 
opportunities for trade and commerce that arise from comparative and competitive advantage, and are not to be missed: thriving markets of all kinds can be found in many border regions, offering bargains not readily available locally. It is not just products, services and finance that are mobile, but people shuttle across boundaries for work, education or tourism; they look for bargains, asylum or just adventure. The more porous a boundary, the greater and keener the human traffic across.

\section{Layout}

This book should prove to be of interest to scholars of political geography, world history, comparative politics, international political economy, governance, international relations, island studies, as well as peace and conflict studies. This is, after all, a unique and thorough collection of a fairly idiosyncratic group of jurisdictions.

Reflective of the nature of the topic, its organisation is also twofold. First is an introductory section. This includes a pithy foreword (by Philip E. Steinberg), which alerts us to some crucial differences between islands and continents; next comes this editorial overview, followed by a synthetic thinkpiece (by Stewart Williams) that looks at the subject matter from a more theoretical angle. It presents a double problematique of politically divided islands. First, because this class of territories does not fit a still dominant disposition to simplify island spaces and their phenomena often in stark binary terms, as glocal spaces perched between closure and openness, interiority and exteriority, singular fixity and diasporic multiplicity. Second, because the state - the basic unit of analysis in political science - does not fit in its conflation with the nation, and less so in these challenging divided polities, requiring in turn an accommodation to new interpretations and manifestations of sovereignty and identity. In both these tensions, there is a critical role for a trans-border, and effectively inter-national, political economy, where boundaries matter for their (re)inscription and social construction as much as for their erasure.

\section{Content review}

The second, and most substantial, section of this book presents a critical exposé of each of today's ten divided inhabited islands. (There are various other uninhabited, and very small, divided islands (Jacobs 2012) and their division is often accidental: they include Märket island, which means, quite aptly, 'the mark', a skerry shared between Sweden and Finland.) Here is a critical exploration of the nature of borders, 


\section{Only Ten: Islands as Uncomfortable Fragmented Polities}

competing claims for full sovereignty, transition to accommodation and settlement, the political economy of trade, migration and co-habitation, typically within a largely descriptive historical framework.

A review of three divided Asian islands comes first. We should not be surprised that the common denominator in all three is the world's largest, exclusively archipelagic state, Indonesia. State formation in this country may be said to have begun during the Second World War, when the territory was occupied by the Japanese, who ended Dutch colonial rule in 1942. But Dutch imperialism in Southeast Asia had been shared begrudgingly for decades with other European powers, particularly the British and the Portuguese. Where such powers ended up sharing islands, permanent political borders have been drawn up, and not always with the full cooperation of those concerned.

We begin with New Guinea, the world's second largest island (after Greenland), currently divided between the independent state of Papua New Guinea and the Indonesian territory of West Papua. The chapter co-authored by Ron May, Evangelia Papoutsaki and Patrick Matbob explores the ambiguous relationship between these two 'brothers'. It diligently reviews the island's colonial history context and the role of the main colonial powers that led to the island's division, along with the post-colonial and cold war legacies that sealed the fate of the island as a divided one. The second part deals with the current geopolitical situation that involves the interests of Indonesia, PNG and, increasingly, Australia. Evidence is presented using both a comparative historical overview as well as an ethnographic, richly descriptive account of border events. There is a rich trans-border political economy in place; one that includes various forms of human displacement.

Borneo (and including much smaller Sebatik Island alongside), the world's third largest island, is today split into three separate political jurisdictions. In his contribution, Taufiq Tanasaldy examines the governance of the island prior to the arrival of European colonisers, the bordering that accompanied the construction of the post-colonial developing states of Indonesia and Malaysia (and resource-rich Brunei deciding to go its own way) and the regional problems and their impacts on the partition of the island in the post-independence period. This chapter looks at the range and extent of cross-border dynamics and exchange, and their relationship to the nation-building pursuits driven by Kuala Lumpur and Jakarta.

The withdrawal of Indonesia from Timor-Leste in 1999 and the international recognition of East Timor's independence in 2002 mark the recent acceptance of the (recent) division of the island of Timor into 


\section{PROOF}

Godfrey Baldacchino 11

two halves: the eastern half - but also including the exclave of Oecusse forming the Democratic Republic of Timor-Leste, and the western half forming part of the Indonesian province of East Nusa Tenggara. The chapter by Anthony Soares charts the formation of the border dividing this island, arising initially from territorial disputes over Timor - the world's 44th largest island - between the Dutch and the Portuguese colonial powers, and then from East Timorese resistance to the eastern half's integration into the Republic of Indonesia. It also considers the border's porosity in terms of contemporary two-way population movements, as well as its strategic use by the governments on both sides in moving individuals out of the jurisdiction where they stand accused of serious crimes. Given its occasional fragility, for many within Timor-Leste the border between east and west has not brought an end to colonial history.

While European powers were contributing to island divisions across the globe, the drama of division was unfolding in Europe as well. Ireland, as Stephen Royle argues in his contribution, has long been caught up in the grip of that dominant island to its east, Great Britain. The Anglo-Normans invaded in 1169; in the 17th century, locals were cleared to make way for British settlers. Resistance was inevitable; strife in 1642, and in 1798 especially, shortly after which came the Act of Union in 1801, which made Ireland - the world's 20th largest island an integral part of the United Kingdom, but was actively resisted, particularly by Ireland's majority Catholic population. In those places, as in Belfast, where the Catholics rubbed up against Protestants, there was constant conflict and tension between competing groups. Matters came to a head during the First World War when in 1916 nationalists rebelled in Dublin (the Easter Rising) when the theoretically United Kingdom was at war, whilst Ulster Protestants died in their thousands on the Somme. After the war, division was inevitable; much of the island could not be held within the UK, whilst in Ulster the Protestant majority areas could not be forced from it. The eventual boundary ensured that six ancient contiguous counties in the northeast were retained in the UK, whilst 26 counties left to form what became the Republic of Ireland. Partition did not solve the political problems; there was bloodshed and violence, most horribly during 'The Troubles' from the 1960s to 1990s. Since then, there has been an uneasy peace and a power-sharing government in Northern Ireland. Meanwhile, there has also been a steady stream of cross-border transactions, legal and otherwise, as citizens on either side seek to exploit the comparative advantages of two markets, as well as to minimize the damage from excessive exposure to their weaknesses. 


\section{Only Ten: Islands as Uncomfortable Fragmented Polities}

'Today, [post-Troubles] one probably does not notice the border has been crossed until observing that the road signage has changed', writes Royle about Ireland. The border in place in Cyprus, in contrast, is a very visible one. As Ahmet Sözen reminds us in his chapter, the conflict on this Eastern Mediterranean island - the 81st largest in the world has been on the UN's agenda for more than five decades. After the collapse of the 1960 Republic of Cyprus as a partnership between the island's two communities (Greek Cypriots and Turkish Cypriots), efforts to reach a solution have proved elusive. More so after the military intervention/invasion and subsequent occupation of Northern Cyprus by Turkey in June 1974, which institutionalised the border and its buffer zone. Things have improved since the opening of the border in 2003, but the main form of cross-border 'trade' remains the movement of day trippers, plus some Turkish Cypriots working in the Greek Cypriot economy. We are also reminded that 3 per cent of Cypriot territory was excised as two British Sovereign Base areas of Akrotiri and Dhekelia in the run-up to the independence of Cyprus from Britain in 1960. This is the world's most complex island division.

Not all divided islands trace their histories to colonialism. The political division of the island of Usedom (in German) and Uznam (in Polish) - for centuries a wholly German island - ensued from the 1945 Yalta Conference and included Poland's annexation of Szczecin, whose economy was closely linked with the functioning of Świnoujście (Swinemünde), the city located at the eastern end of Usedom. In Poland, the territory was regarded as a part of the Regained Lands and a war trophy compensating for the loss of Polish eastern territories to the Soviet Union. The Germans, on the other hand, found it difficult to accept the loss of the territory and the resettlement of its German population. Nevertheless, the division was recognised first by various bilateral treaties, and finally by Poland's accession to the European Union in 2004, as well as the abolition of border controls in 2007 (Poland's accession to Schengen Area). The result - a fast-paced economic, cultural and political unification of both parts of the island - is critically described in the chapter by Maciej Jedrusik. Today, it is almost impossible to regard Usedom/Uznam as a divided territory.

We head out next to the Caribbean, and the world's only island shared by the full territories of two sovereign states. A large Caribbean island 22nd largest in the world - is shared by two sovereign states: Haiti and the Dominican Republic (DR). It is known by at least three different names: Hispaniola, Saint-Domingue or Quisqueya. This ambiguity of nomenclature, as Marie Redon reminds us in her piece, is redolent of 


\section{PROOF}

Godfrey Baldacchino 13

a fractured insularity, reinforced by the stark economic, social and cultural differences that pertain to the two countries that share this island, separated - and united - by a $300-\mathrm{km}$ border. The island is split asunder by this historically forged space: a border, a frontier, an interface, a transit zone for goods, workers and migrants. Even the landscape looks different on either side. With long years as a plantation economy driven by slave labour on the west and an extensive livestock industry with grazing pastures on the east, distinct socio-economic systems have developed in parallel. These have, in turn, impacted upon not just the histories but even the characterisations and the bilateral relations of the two neighbouring states and their peoples. Even though an international frontier suggests a pause and break to mobility, the HaitiDR border plays a significant role in facilitating the construction of a hybrid, pan-island culture: whether it deals with transnational alliances carved through marriage, or Haitian labour conscripted to work in the DR economy.

As for the much smaller Sint Maartin/St Martin, its history of division dates from the Treaty of Concordia (1648). In his chapter, Steven Hillebrink traces the division of this Caribbean island between the French and the Dutch, up to the recent completion of constitutional reforms on both sides. A long history of multiple jurisdictions has affected the culture, economy and other aspects of life on this island. On the one hand, Sint Maartin/St Martin serves as an example of how one island can be administered by many governments (France, Guadeloupe, EU, Holland, the Netherlands Antilles, along with the autonomous Sint Maarten and St Martin governments) with very few border disputes. Yet, on the other hand, there are (failed) attempts at nation building (at least on the Dutch side) and a feeling that the metropolitan governments have contributed to dividing a society which used to be more united than it is now. Various attempts at cooperation between governments have failed, although a new treaty regulates a form of shared border control. There has also been of late a strong and almost simultaneous movement on both sides of the island towards a separate constitutional status; this new development may affect the chances of both sides becoming united under a single government in the future.

We next head south, to Isla Grande de Tierra del Fuego - the world's 29th largest island - at the southern tip of South America, split as the result of an 1881 boundary treaty that allocated the eastern portion to Argentina and the remainder to Chile. A dispute over adjacent smaller islands intensified in the late 1970s into preparation for a conflict that 


\section{Only Ten: Islands as Uncomfortable Fragmented Polities}

was fortunately avoided. While some tensions persist, the island is now the site for profitable mineral extraction, tourism and trout fishing. The chapter by Peter van Aert addresses the origins of the island's division in the context of nation building by both Argentina and Chile, the history of disputes on the island, the difficulties in the management and protection of natural heritage in a divided island and the likely pressures on regional management in forthcoming decades.

We return to Asia, where we have left Bolshoi Ussuriiski (in Russian) or Heixiazi (in Chinese Mandarin) for last. Along with Tarabarov Island, this was one of the disputed spaces between Russia and China, and lying close to the Russian city of Khabarovsk, between the rivers Amur and Ussuri. Since the Aigun Treaty of 1958 stipulated that the left bank of the Amur belonged to Russia, possession of the largest islands on the riverborder has been a sore point in Sino-Russian relations. After the Chinese Eastern Railway incidents in 1929, when Russia expelled Chinese residents from the island, China has persistently claimed Heixiazi Island as its own. A Sino-Russian military clash on Damanskii Island in 1969 was triggered by assertive and uncompromising claims on Heixiazi Island. China and Russia eventually concluded an agreement in 1991, but the Sino-Russian 'deal' on Heixiazi Island, based on a 'fifty-fifty' solution, was only secured in 2004, and started being implemented after 2008. In his chapter, Akihiro Iwashita regales us with the fine details of this division and of its operationalisation, confirming that, indeed, the devil is in the details.

Meanwhile, what next? An 'independence referendum' in Scotland slated for 2014 shifts the spotlight to the island of Great Britain, the 9th largest island in the world. Notwithstanding its avowed status as a multinational political formation, the 'national' institutions of this assumed 'nation'-state tend to present themselves through the monofocal prism of the dominant partner as the 'island race' of England's historical lineage, the 'sceptred isle' of patriotically English cultural referents. At the heart of the notion of 'Great Britain' as a unitary island polity lies the union first (since 1536) of Wales and England and then (since 1707) of Scotland to that union. The concluding chapter, penned by Ray Burnett, examines the tensions within the Scotland-England relationship from a distinctively Scottish and subaltern viewpoint. After outlining the reasons why the relationship is disintegrating as the ideological unction of 'Britishness' thins and evaporates, from Shetland to Cornwall, it considers the repercussions of 'break-up' within and beyond Scotland for the UK's other constituent units. Far from abrasion and rupture being a prospect of the future, division has always been an ever-present reality 
of this creaking island polity, one that has been ignored or overlooked for far too long (Cartrite 2012). The chapter concludes that the implications of the Anglo-British imperial project had profound implications not only for the internal crafting of the cultural constructs of its own small island periphery, but for the multiplicity of its island territories across the globe (Matthews and Travers 2012).

\section{Conclusion}

In his novel The Stone Raft, Literature Nobel Laureate José Saramago conjures up a whimsical tale of how one day, inexplicably, the Iberian Peninsula simply breaks free from the rest of continental Europe, and starts to draft westwards across the Atlantic. (Gibraltar, meanwhile, remains rigidly stuck in its place, and becomes an island.) This geophysical oddity is merely the backdrop to Saramago's story, but it offers us a few interesting insights relevant to this collection. The Spaniards and the Portuguese, finding themselves thrust out on the high seas alone and together, are suddenly looked upon, to their respective dismay, as Iberians by the rest of the world. What was a peninsula, now an island, has been reduced 'to a single country' (Saramago 1995: 249); and Spain and Portugal are proposed as the signatories to a 'joint and complementary strategy' (ibid.: 263) to chart their common future. Even in fiction, and re-echoing Popeye, the pressure is there to dismember international borders on islands and to chastise them for highlighting and constructing differences rather than commonalities between people, cultures, customs, labour markets, networks of conviviality, consumption and exchange. Why at all should there be an international political economy of divided islands?

\section{References}

Agnew, J. 1994. The territorial trap: the geographical assumptions of international relations theory. Review of International Political Economy, 1(1): 53-80.

Anckar, D. 2005. Decentralisation in microstates: where, how and why? Canadian Review of Studies in Nationalism, 32(1-2): 109-120.

Baldacchino, G. 2005a. The representation of islands. Editorial Introduction. Geografiska Annaler B, 87(4): 247-251.

Baldacchino, G. 2005b. The contribution of social capital to economic growth: lessons from island jurisdictions. The Round Table: Commonwealth Journal of International Affairs, 94(378): 35-50.

Baldacchino, G. 2010. Island enclaves: Offshoring, creative governance and subnational island jurisdictions. Montreal, QC: McGill-Queen's University Press. 
16 Only Ten: Islands as Uncomfortable Fragmented Polities

Baldacchino, G. and Hepburn, E. (eds.) 2013. Independence movements in subnational island jurisdictions. London: Routledge.

Baum, T. G. 1993. The fascination of islands: a tourist perspective. In D. G. Lockhart and D. Drakakis-Smith (eds.) Island tourism: Trends and prospects. London: Mansell, 21-35.

Bigo, D. 2007. Detention of foreigners, states of exception, and the social practices of control of the Panopticon. In P. Kumar Rajaram and C. Grundy-Warr (eds.) Borderscapes: Hidden geographies and politics at territory's edge. Minneapolis, MN: University of Minnesota Press, 3-34.

Butler, J. 2002. Guantánamo Limbo. The Nation, 1 April. http://www.thenation. com/doc/20020401/butler

AQ1 Cartrite, B. 2012. The impact of a Scottish referendum on ethnoregionalist movements in the British Isles. Commonwealth and Comparative Politics, 50(4): forthcoming.

Edmond, R. and Smith, V. 2003. Islands in history and representation. London: Routledge.

Fletcher, G. P. 2004. Black hole in Guantánamo Bay. Journal of International Criminal Justice, 2(1): 121-132.

Grydehøj, A., Grydehøj, A. and Ackrén, M. 2012. The globalisation of the Arctic: negotiating sovereignty and building communities in Svalbard, Norway. Island Studies Journal, 7(1): 99-118.

Hemmings, A. D., Rothwell, D. R. and Scott, K. N. (eds.) 2012. Antarctic security in the twenty-first century: Legal and policy perspectives. Abingdon: Routledge.

Jacobs, F. 2011. In praise of borders. New York Times, 24 October. http:// opinionator.blogs.nytimes.com/2011/10/24/in-praise-of-borders/

Jacobs, F. 2012. One island, two countries. New York Times, 24 April. http:// opinionator.blogs.nytimes.com/2012/04/24/one-island-two-countries/

Jepson, A. 2006. Gardens and the nature of rootedness in Cyprus. In Y. Papadakis, N. Peristianis and G. Welz (eds.) Divided Cyprus: Modernity, history and an island in conflict. Bloomington, IN: Indiana University Press, 158-175.

Kaplan, A. 2005. Where is Guantánamo? American Quarterly, 57(3): 831-858.

Lopez, E. H. 2010. Guantánamo as a 'legal black hole': a base for expanding space, markets, and culture. University of San Francisco Law Review, 45: 141-214.

Matthews, J. and Travers, D. 2012. Islands and Britishness: A global perspective. Newcastle-upon-Tyne: Cambridge Scholars Publishing.

McBride, D. 1999. Migrants and asylum seekers: policy responses in the US to immigrants and refugees from Central America and the Caribbean. International Migration, 37(1): 289-317.

McIntyre, W. D. 2012. The partition of the Gilbert and Ellice islands. Island Studies Journal, 7(1): 135-146.

McMahon, E. 2010. Australia, the island continent: how contradictory geography shapes the national imaginary. Space and Culture, 13(2): 178-187.

More, T. 1516/2002. Utopia. http://etext.lib.virginia.edu/toc/modeng/public/ MorUtop.html

Muller, K. 2012. Mayotte between Europe and Africa. In R. Adler-Nissen and U. P. Gad (eds.) Sovereignty games: The overseas countries and territories of the European Union. London: Routledge, forthcoming.

Newitt, M. 1984. The Comoro islands: Struggle against dependency in the Indian Ocean. Aldershot: Gower. 
Peckham, R. S. 2003. The uncertain state of islands: national identity and the discourse of islands in nineteenth-century Britain and Greece. Journal of Historical Geography, 29(4): 419-515.

Redfield, P. 2000. Space in the tropics: From convicts to rockets in French Guiana. Berkeley, CA: University of California Press.

Reid-Henry, S. 2007. Exceptional sovereignty? Guantánamo Bay and the recolonial present. Antipode, 39(4): 627-648.

Royle, S. A. 2001. A geography of islands: Small island insularity. London: Routledge. Saramago, J. 1995. The stone raft. Translated by G. Pontiero. New York: Harvest Book/Harcourt.

Segar, E. C. 1931/2007. E. C. Segar's Popeye: Well, blow me down! Seattle, WA: Pantagraphics Books.

Srebrnik, H. F. 2004. Small island nations and democratic values. World Development, 32(2): 329-342.

Swift, J. 1726. Gulliver's travels: Or, travels into several remote nations of the world, p. 256. http://www.literaturepage.com/read/gulliverstravels.html

United States Supreme Court 2004. Rasul et al. v. Bush, President of the United States et al. Decided: 28 June. http://www.ilsa.org/jessup/jessup08/basicmats/ usscrasul.pdf 


\section{PROOF}

\section{QUERIES TO BE ANSWERED BY AUTHOR (SEE MARGINAL MARKS)}

IMPORTANT NOTE: Please mark your corrections and answer to these queries directly onto the proof at the relevant place. Do NOT mark your corrections on this query sheet.

\section{Chapter 1}

\begin{tabular}{lcc}
\hline Query No. & Page No. & Query \\
\hline AQ1 & 16 & $\begin{array}{l}\text { Please update the page range for refer- } \\
\text { ence 'Cartrite (2012). }\end{array}$ \\
\hline
\end{tabular}

